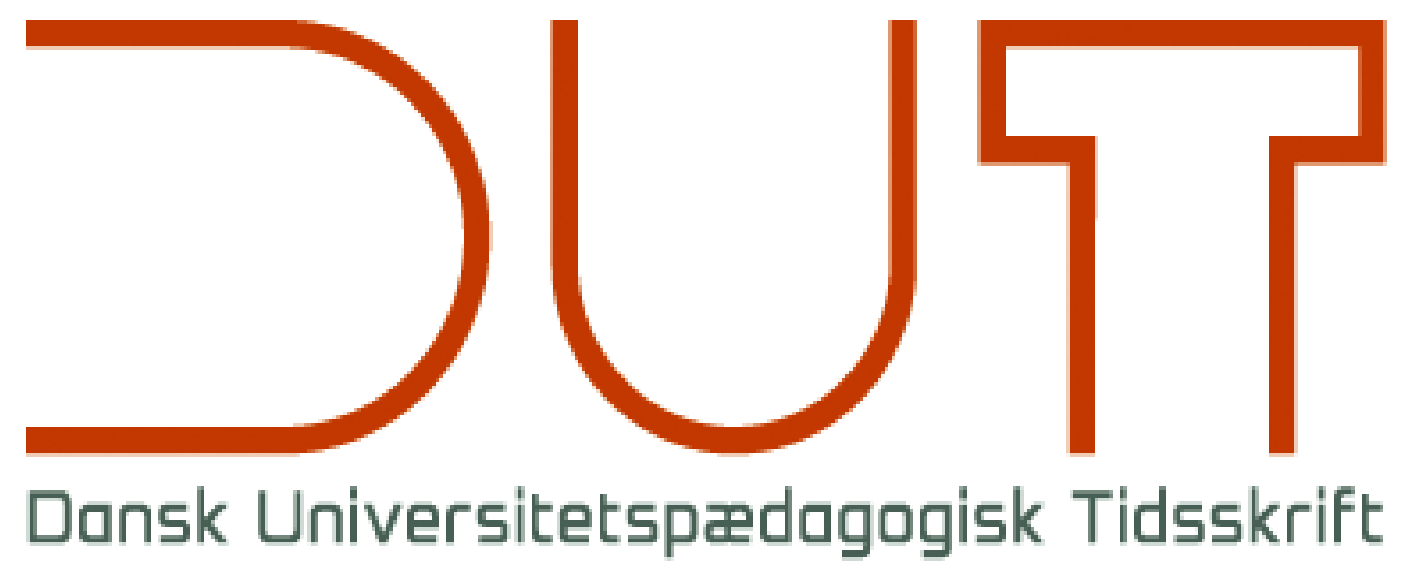

Tema

Undervisningens teknologier og teknikker

Årgang 15 nr. 28 / 2020

Titel

Musik- og kunstfestival som praksisnært læringsmiljø i ingeniøruddannelse

Forfattere

Lasse Skovgaard Jensen, Birgitte Rasmussen

Sidetal

$31-50$

Udgivet af

Dansk Universitetspædagogisk Netværk, DUN

URL

> http://dun-net.dk/

Betingelser for brug af denne artikel

(C) Copyright
Denne artikel er omfattet af ophavsretsloven, og der må citeres fra den. Følgende betingelser skal dog være opfyldt:

- Citatet skal være i overensstemmelse med "god skik"

- Der må kun citeres „i det omfang, som betinges af formålet“

- Ophavsmanden til teksten skal krediteres, og kilden skal angives ift. ovenstående bibliografiske oplysninger.

DUT og artiklens forfatter 


\title{
Musik- og kunstfestival som praksisnært læringsmiljø i ingeniøruddannelse
}

\author{
Lasse Skovgaard Jensen ${ }^{a, 1}$, Birgitte Rasmussen ${ }^{b}$ \\ ${ }^{a}$ Center for Entrepreneurskab i Teknologi, DTU \\ bDTU Management Engineering
}

Faglig artikel, fagfællebedømt

\begin{abstract}
Entreprenørskab og innovation står højt på den politiske dagsorden. Universiteterne forventes at bidrage til at øge innovationskapaciteten i samfundet ved pædagogiske tiltag, der styrker de studerendes innovationskompetencer. Danmarks Tekniske Universitet og Roskilde Festival har siden 2010 etableret et samarbejde med intentionen om at rammesætte et autentisk praksisnært læringsmiljø, der kan understøtte og styrke udvikling af de studerendes personlige og professionelle innovative kompetencer. $\mathrm{Vi}$ argumenterer for, at festivalen kan karakteriseres som et ingeniørfagligt læringsmiljø med mulighed for udfoldning af professionel ingeniørmæssig problemløsning. I perioden 2010-2018 har mere end 750 studerende haft studieprojekter og undervisningsaktiviteter i dette regi. Formen og omfanget af samarbejdet er udfordrende og ressourcekrævende, og for at få samarbejdet til at blomstre og opnå de ønskede resultater, er det nødvendigt at etablere et robust institutionelt set-up, som kan understøtte og facilitere aktiviteterne.
\end{abstract}

\section{Indledning}

Entreprenørskab og innovation har høj strategisk prioritet på Danmarks Tekniske Universitet (DTU) (DTU 2018). DTU har over de senere år investeret betydelige midler i at understøtte innovation og entreprenørskab for ansatte og studerende på DTU (IRIS 2018), og en del aktiviteter har været rettet mod at udvikle og understøtte en innovationskultur blandt de ingeniørstuderende. Ønsket er et tæt samarbejde mellem virksomheder og studerende med fokus på konkrete problemstillinger, projekter og løsninger. Intentionen er, at de studerende tilbydes muligheder for at afprøve idéer og prototyper og få sparring med virksomheder.

Samarbejde med virksomheder og organisationer tilskrives ofte at være meningsfulde læringsmiljøer i universitetsuddannelserne i forhold til at udfordre og udvikle de studerendes innovative og entreprenante kompetencer (f.eks. Jørgensen og Hjortsø 2015, Malmqvist et al. 2015). Denne form for kompetenceudvikling kan understøttes ved at tilbyde autentiske innovationsmiljøer, som giver de studerende mulighed for at arbejde med praksisnære problemstillinger i en sammenhæng, der er både udfordrende og attraktiv for unge mennesker.

DTU er et internationalt teknisk eliteuniversitet, som i 2018 havde omkring 10300 studerende og 5800 ansatte. DTU udbyder en pallette af ingeniøruddannelser med 17 diplomuddannelser, 22 bacheloruddannelser og 32 kandidatuddannelser. DTU er Danmarks største ingeniøruddannelsessted, og DTU arbejder med uddannelse, forskning, myndighedsrådgivning og innovation. (https://www.dtu.dk/om-dtu)

1Kontakt:Isje@dtu.dk 
DTU har siden 2010 haft et samarbejde med musik- og kunstfestivalen Roskilde Festival (RF). Hvert år etableres en midlertidig festivalplads, hvor den eneste permanente infrastruktur er relativt få toiletter og drænrør (Figur 1), og denne midlertidige etablering giver en række udfordrende ingeniørmæssige problemstillinger (se www.roskilde.dtu.dk). DTU's pædagogiske motivation er at tilbyde et ingeniørfagligt læringsmiljø, der kan understøtte, udfordre og udvikle ingeniørstuderendes innovative og entreprenante kompetencer. Artiklen har primært fokus på etablering og facilitering af det ingeniørfaglige indhold i læringsmiljøet og mindre fokus på den praktiske organisering.

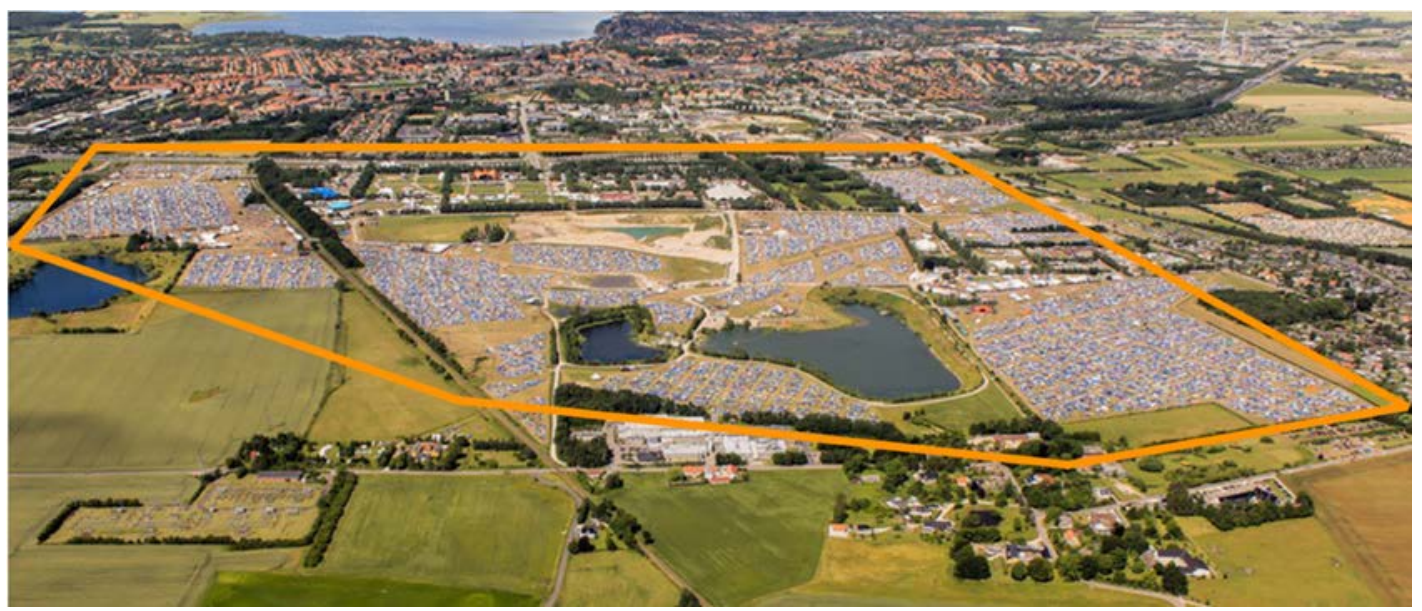

Figur 1. Luftfoto af Roskilde Festival og dens omgivelser. Den orange kontur omkranser festivalpladsen med tilhørende campingareal, som samlet er ca. 400.000 m2. Omkring 130.000 gæster og frivillige deltager i festivalen. I baggrunden ses Roskilde og fjorden.

Festivalen har siden 1971 været gennemført hvert år i en uge i starten af juli med musik fra 8 scener og andre kunstneriske oplevelser og med Orange Scene som festivalens ikon og vartegn (Figur 2). RF er en non-profitorganisation med omkring 60 fastansatte medarbejdere. Dette gør festivalen fuldstændig afhængig af frivilligt arbejde. Omkring 800 personer er engagerede i arbejdet hele året, og dette tal stiger til omkring 32.000 frivillige under selve festivalen. Omkring 80.000 gæster køber billet til hele festivalen og omkring 20.000 køber billetter til enkelte dage (Roskilde Festival 2018). Dette antal gør RF til den største nordeuropæiske musikbegivenhed. Størstedelen af gæster og frivillige camperer på midlertidige campingpladser i umiddelbar nærhed af festivalen.

Festivalen ønsker at præsentere et bredt spektrum af kunstneriske oplevelser for sine gæster og frivillige samt en velfungerende infrastruktur. De studerende samarbejder med festivalens medarbejdere og frivillige i et professionelt set-up, og såvel kunst som infrastruktur efterspørger mange aspekter af ingeniørarbejde, f.eks. akustik, ressourceoptimering, affaldshåndtering, sanitet, interaktive installationer, sikkerhed, bæredygtighed m.m. Målgruppen for de studerendes projekter er således både de professionelt ansvarlige for festivalens infrastruktur og kunstneriske indhold samt festivalens publikum. 
Festivalen kan karakteriseres som 130.000 entusiastiske, fortrinsvis unge mennesker på meget lidt plads, og dette medfører et stort pres på infrastrukturen. Alle faciliteter og serviceydelser har mange brugere døgnet rundt, og brugerne anvender ofte disse på utraditionelle og uforudsete måder. Disse ekstreme forhold gør festivalen til et relevant miljø til at afprøve ideer samt teste og eksperimentere med nye produkter og serviceydelser med mulighed for at få sparring fra både festivalen som eventarrangør og dens publikum. Når studerende afprøver en prototype, kan det ud over det læringsmæssige udbytte give et fingerpeg om, hvorvidt deres ide potentielt kan have tilstrækkelig robusthed og relevans til at retfærdiggøre videre udviklingsarbejde og afprøvning i andre testmiljøer.

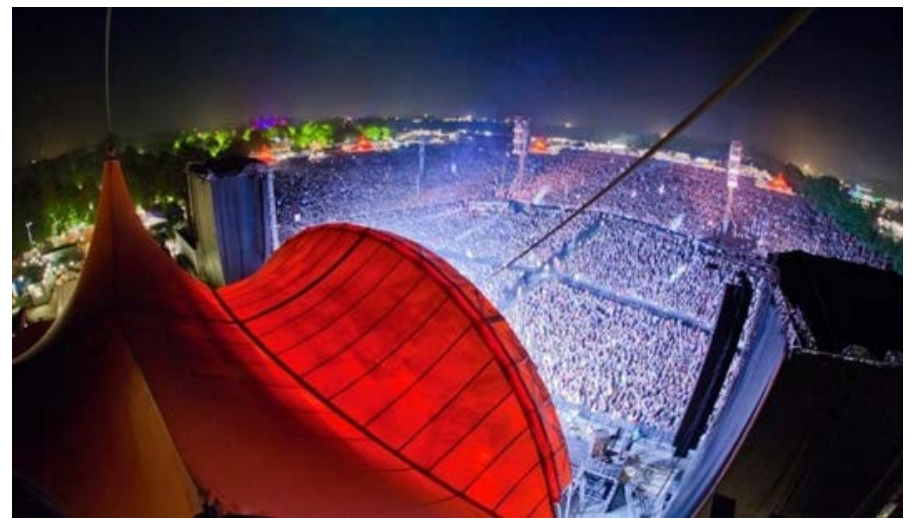

Figur 2. Koncert på Orange Scene

Denne artikel beskriver erfaringer og teoretiske refleksioner fra samarbejdet mellem DTU og RF med fokus på festivalen som et praksisnært innovativt læringsmiljø for ingeniørstuderende. I perioden fra 2010 til 2018 har mere end 750 studerende haft undervisningsaktiviteter og projekter i dette regi, og DTU har hvert år haft en stand som mødested og udstillingsområde (Figur 3).

Vores erfaringer er, at festivalen er et unikt læringsmiljø for de studerende til at designe, implementere, afprøve og verificere ideer og prototyper. Artiklens forfattere har igennem den ovennævnte årrække - godt hjulpet af kolleger hos DTU og RF - varetaget forskellige roller som facilitatorer og koordinatorer for læringsmiljøet. Vores beskrivelser og vurderinger af samarbejdet bygger derfor på vores personlige erfaringer samt diskussioner med kolleger og studerende. På den ene side kan dette betragtes som en mulig begrænsning for validiteten og neutraliteten af vores udsagn, men på den anden side muliggør dette en indsigt i en række særlige nuancer og refleksioner omkring samarbejdet og dets læringsmiljø. 


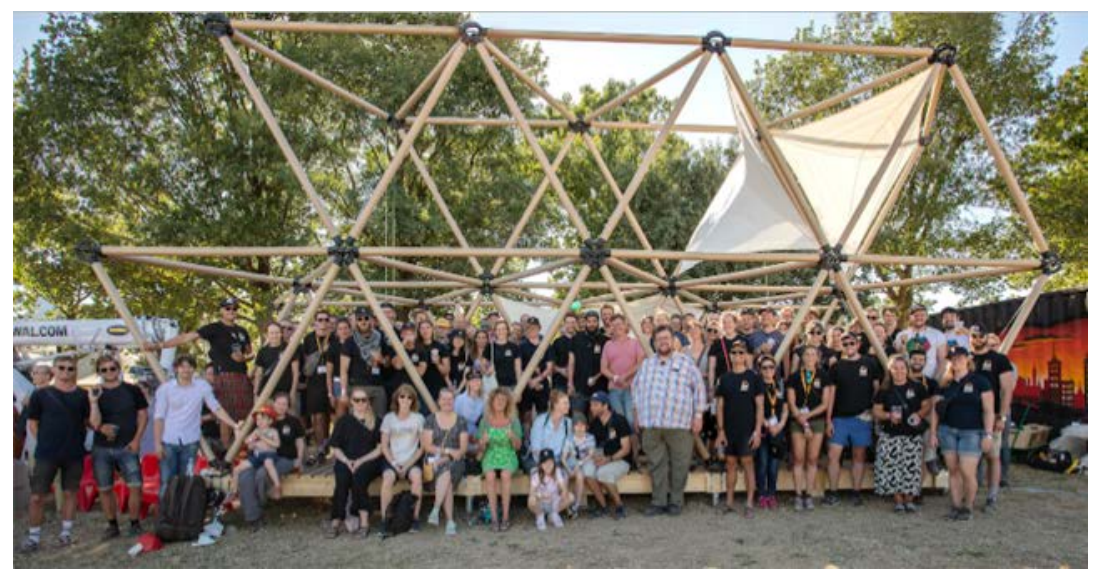

Figur 3. Ingeniørstuderende og DTU-ansatte ved 'Tech Lab' i 2018, som fungerer som mødested og udstillingsområde under festivalen (Foto: Mikal Schlosser).

\section{Roskilde Festival som et praksisnært læringsmiljø for ingeniørstuderende}

Det er intentionen, at læringsmiljøet skal være tilgængeligt for alle DTU's ingeniøruddannelser. Det har derfor været hensigten at tilbyde en platform med en mangfoldighed af muligheder, der kan favne et bredt spektrum af ingeniørfaglige discipliner og pædagogiske principper. For DTU er det afgørende, at aktiviteter i forbindelse med festivalen er meriterende i den enkelte studerendes uddannelse, og derfor er faglig og pædagogisk kvalitet af stor betydning. Dette imødekommes ved, at læringsmiljøet tilrettelægges således, at den enkelte underviser eller vejleder er ansvarlig for at sikre meningsfulde læringsmål, curriculum og undervisningsaktiviteter inden for netop deres fagområde. Det skal understreges, at det er intentionen, at vejlederen kun får begrænset medejerskab over et projekts problemstilling og løsninger, da de studerende selv skal tage ansvar og ejerskab for både projektet og arbejdsprocessen.

Der er to overordnede pædagogiske tilgange, hvor det skal bemærkes, at de studerende i processen kan få sparring fra DTU og RF:

- Den ene er principperne i den problemorienterede og projektorganiserede undervisningsform (Lehman et al. 2004; Krogh og Wiberg 2013, Askehave et al. 2015; Geraldi et al. 2017). For at komme i betragtning skal de studerende selv identificere, definere og formulere en problemstilling, de finder relevant at bidrage med på festivalen, og de skal aflevere en projektplan med formål, metode, ressourceforbrug og forventet resultat.

- Den anden er etablering af et læringsmiljø for undervisning gennem innovation, hvor lærings-målet er, at de studerende skal opnå innovationskompetencer og udvikle en adfærd, som styrker deres evne til selv at være innovative i et tværfagligt miljø. Innovationspædagogik handler om at bringe innovationsprocessen ind i fagdisciplinær kontekst, hvor den studerende ved at arbejde med sin egen faglighed udvikler sine kompetencer til at skabe værdi for aftagerne gennem sin faglige viden (Jørgensen og Hjortsø 2015).

I det følgende beskriver vi og argumenterer for, hvordan koncepterne 'CDIO' (Conceive, Design, Implement, Operate), 'Living Labs' (Living Laboratories) og 'Communities of Practice' kan bidrage til at karakterisere festivalen som læringsmiljø i ingeniøruddannelserne. Intentionen med at kombinere disse tre koncepter er at rammesætte et autentisk, perspektiverende og praksisnært læringsmiljø inden for ingeniørarbejde og innovation, der kan understøtte udvikling af de studerendes professionelle fagdisciplinære og samarbejdskompetencer. 


\section{CDIO-konceptet}

DTU-RF-samarbejdet skal bidrage til at uddanne de studerende i professionel ingeniørmæssig problemløsning. I ingeniøruddannelserne er CDIO et udbredt koncept til at beskrive de faser med tilhørende kompetencer, som ingeniørens problemløsning gennemgår. CDIO er et akronym for: Conceive, Design, Implement, Operate. Konceptet anviser principper for udvikling og kvalitetssikring af ingeniøruddannelser med udgangspunkt i ingeniørarbejdets virkelighed (Crawley et al. 2014). CDIO-konceptet blev oprindeligt udviklet i et samarbejde mellem Massachusetts Institute of Technology, Chalmers Tekniska Högskola, Kungliga Tekniska Högskolan og Linköping Universitet.

I korthed kan konceptet beskrives via fire projektfaser, som vist i Tabel 1.

\begin{tabular}{|c|c|c|}
\hline \multirow{2}{*}{ Conceive } & Mission & \multirow{2}{*}{$\begin{array}{l}\text { I denne fase sker en erkendelse af problemstillinger, nye } \\
\text { ideer opstår, og overordnede perspektiver og problemer } \\
\text { afdækkes }\end{array}$} \\
\hline & conceptual design & \\
\hline \multirow{2}{*}{ Design } & preliminary design & \multirow{2}{*}{$\begin{array}{l}\text { Dernæst følger en designfase, hvor der udtænkes løsninger } \\
\text { til problemer, herunder skitsering af designløsninger }\end{array}$} \\
\hline & detailed design & \\
\hline \multirow{2}{*}{ Implement } & element creation & \multirow{2}{*}{$\begin{array}{l}\text { Under implementeringen realiseres valgte løsninger som en } \\
\text { prototype på en proces, et produkt eller et system }\end{array}$} \\
\hline & systems' integration test & \\
\hline \multirow{2}{*}{ Operate } & life cycle support & \multirow{2}{*}{$\begin{array}{l}\text { I sidste fase sættes fokus på produkters anvendelse og drift } \\
\text { af processer, produkter eller systemer }\end{array}$} \\
\hline & evolution & \\
\hline
\end{tabular}

Tabel 1. Conceive-Design-Implement-Operate som en livscyklusmodel for et produkt, en proces eller et system (DTU 2013 \& Crawley et al. 2014).

CDIO som uddannelseskoncept lægger vægt på at træne viden, færdigheder og kompetencer i en sammenhæng, som afspejler ingeniørens arbejdsform. Det vægtes, at grundige teoretiske kundskaber bringes i spil, men at meningsskabelsen er forankret i, at disse anvendes til værdiskabelse for individ, organisation og samfund (Aarhus Universitet 2012, Malmqvist et al. 2015).

Med reference til Crawley et al. (2014) er der tre overordnede målsætninger for CDIOkonceptet:

- Mestre en dybere faglig forståelse af fundamental teknisk viden.

- Føre til udvikling og implementering af nye produkter, processer og systemer.

- Forstå den samfundsmæssige vigtighed og strategiske betydning af forskning og teknologisk udvikling.

Samarbejdet mellem DTU og RF giver mulighed for projekter, der gennemløber hele den livscyklus, som CDIO-konceptet rammesætter, og derfor er det relevant at have dette koncept som overordnet ramme for læringsmiljøet:

- Conceive: Der skal være et klart perspektiv og målsætning i projektet. Projektet skal være ny-skabende og relevant for festivalen. Her skal det bemærkes, at mange studerende selv har været gæster på festivalen og bruger denne erfaring til at formulere projektideer. 
- Design: Dernæst skal de studerende udtænke og skitsere designløsninger, som drøftes og diskuteres med både vejleder og repræsentant for festivalen.

- Implement: De studerende skal overveje implementering og afprøvning af designløsningen, herunder om afprøvningen stiller særlige krav til testmiljøet, f.eks. infrastruktur.

- Operate: De studerende skal redegøre for, om produktet eller serviceydelsen kan anvendes i en bredere kontekst, dvs. andre sammenhænge end på festivalen.

\section{Living Laboratories}

Konceptet Living Labs beskrives ofte som et brugercentreret åbent innovationssystem, der opererer $\mathrm{i}$ en territorial kontekst (f.eks. et byområde) og samtidig integrerer forsknings- og innovationsprocesser inden for et partnerskab mellem offentlige og private organisationer (Almirall \& Wareham 2011). Living Labs beskrives ofte som en attraktiv måde at engagere private virksomheder, borgere, forskere og offentlige organisationer i et gensidigt og udbytterigt læringsforløb (Miettilnen 2002). Konceptet er blevet præsenteret som kombinerende innovationsmiljøer og innovationsstrategier (Bergvall-Kareborn \& Stahlbrost 2009) med henblik på innovation i brugerdrevne fællesskaber, hvor alle involverede betragtes som medskabere, og aktiviteterne er præget af videndeling, samarbejde og eksperimenter (Cohen 2009). Living Labs har herved en række ligheder med åbne innovationshubs, som eksempelvis Makerspaces og FabLabs, der i deres 'institutionaliserede' form ofte etableres for at understøtte et produkt- og prototypeorienteret innovationsmiljø hos eksempelvis erhvervsvirksomheder, uddannelsesinstitutioner og kommuner (Jensen et al. 2016). Herved repræsenterer Living Labs en bredere målsætning end teknologifokuseret udvikling af produkter eller prototyper

Dell'Era og Landoni (2014) understreger særligt to karakteristika for Living Labs: i) et autentisk miljø for test og eksperimenter og ii) involvering af potentielle brugere, der er bevidste om deres medvirken i innovationsprocessen. Med reference til disse karakteristika argumenterer vi for, at RF som læringsmiljø tager form som et Living Lab, hvor der skabes mulighed for test af designløsninger i samarbejde med en professionel partner. Det skal dog understreges, at intentionen med Living Labs generelt set ikke er uddannelse men derimod oftest innovation.

\section{Communities of Practice - graensegangere og granseobjekter}

Begrebet 'Commuties of Practice (CoP)' har flere betydninger i litteraturen, og her benyttes begrebet i Wengers et al (2002) forståelse som 'communities of practice' med vægt på kognitive aspekter af dets funktion: "groups of people who share a concern, a set of problems, or passion about a topic, and who deepen their knowledge and expertise in this area by interacting on an on-going basis". Et CoP består af tre grundlæggende byggesten, der fungerer i samspil (Marstrand, 2005):

- Et videnområde, som udgør det emnemæssige indhold.

- Et fællesskab karakteriseret ved deltagernes gensidige engagement i forhold til videnområdet.

- En praksis som fællesskabets deltagere sammen har udviklet for effektivt at håndtere opgaver og udfordringer inden for videnområdet.

Både DTU og RF kan beskrives som organisationer bestående af flere CoP'er. Samarbejde mellem CoP'er foregår gennem de såkaldte grænseobjekter, som danner grundlag for en fælles forståelse og samarbejde mellem disse (Bowker \& Star, 1999). I praksis skal grænseobjekter både være i stand til at krydse grænser mellem fagområder og samtidig være i stand til 
at opretholde en eller anden form for faglig identitet for de involverede parter. Grænseobjekter kan til eksempel være teknologiske objekter eller videnobjekter. Grænseobjekter er centrale af to grunde: (i) de studerendes læring gennem grænseobjekter og (ii) det institutionelle set-up til facilitering af grænseobjekter. Med reference til Akkerman og Bakker (2011) kan interaktionsprocessen mellem medlemmer af CoP'er betragtes som en vital ressource i læring, da processen med at identificere og formulere grænseobjekter involverer hensyntagen til flere forskellige perspektiver og aktørsynspunkter. Dette indebærer en refleksionsproces, hvor de studerende udviser en adfærd rettet mod at være åbne over for andre menneskers måde at tænke på, og hvordan deres egne faglige kompetencer og perspektiver kan bidrage til fælles perspektiver og forståelse mellem CoP'erne. Læring i denne sammenhæng skal forstås forholdsvis bredt som opbygning af en ingeniørfaglig identitet og udvikling af kompetencer for samarbejde mellem organisationer. En væsentlig del af læringen ligger således i de studerendes dialog og meningsskabelse med deres kontaktpersoner hos RF i forhold til specifikke detaljer i projektet. Processen omkring facilitering af grænseobjekter understøttes af et institutionelt set-up, som beskrives detaljeret i det følgende afsnit.

Der kan ydermere drages paralleller til produktudviklingslitteraturen, som er et centralt fagområde i mange ingeniørdiscipliner. Her foreskriver majoriteten af udviklingsmodeller aktiviteter, hvor produktudviklingsteamet opfordres til at eksponere tidlige prototyper af et fremtidigt produkt overfor relevante eksterne aktører. Dette netop med den hensigt, at prototypen kan agere grænseobjekt imellem forskellige CoP'er med samme målsætning, som beskrevet herover. (Cross 2001), (Ulrich \& Eppinger, 2007), (Andreasen et al. 2015).

\section{Organisering af samarbejde og facilitering af læringsmiljøet}

Vi arbejder i snitfladen mellem aktører fra to store og meget forskellige organisationer. Vi har fokus på, at det enkelte studieprojekt har et ingeniørfagligt læringsindhold, og at projektet er relevant for festivalen. Vigtige elementer i samarbejdet har derfor været at facilitere og koordinere samarbejdet på to måder: (i) faciltere samarbejdet og matche relevante samarbejdspartnere i hvert enkelt projekt samt (ii) kontinuerligt arbejde på at bygge bro mellem de to organisationer. Begge disse opgaver er for krævende og omfattende for de enkelte studerende, og derfor har organisering af samarbejdet haft stor opmærksomhed og betydning.

Det er vores erfaring, at det er både sjovt og givende at facilitere studiesamarbejdet mellem DTU og RF, men det er krævende, og der er mange udfordringer i form af flygtige dynamikker, praktiske problemer samt konstant udskiftning af persongalleriet blandt DTU's studerende og festivalens frivillige. Vores erfaringer er på linje med andres erfaringer for samarbejde mellem universiteter og eksterne partnere om studieprojekter, f.eks. Nielsen (2015), som oplister følgende fordele og ulemper: forskelle i studieordninger, holdninger blandt de studerende, skepsis i studienævn, besvær for underviserne, forskelle i semesterstrukturer, forskelle i kursustyper og økonomisk støtte.

\section{Projektarbejde på tvaers af discipliner og organisationer}

Mange studerende kan have vanskeligheder med at præcisere og formulere en problemstilling. Særligt har det vist sig krævende at være præcis omkring projektets relevans for aftageren, herunder det forventede resultat. I den indledende fase kommer principperne fra CDIOkonceptet således i anvendelse. Dertil kommer, at mange aktører hos festivalen - forståeligt nok - ikke har erfaring med uddannelser, studieordninger og forskellige studerendes faglige niveau og derfor kan have forestillinger og forventninger, der ikke er velafstemt med de for- 
ventelige resultater. Facilitering og koordinering er derfor nøgleaktiviteter i samarbejdet. Rollen som facilitatorer og koordinatorer for aktiviteterne i læringsmiljøet kan beskrives som værende brobyggere i snitfladen mellem aktører og discipliner fra de to organisationer. Vi mener, at konceptet 'Communities of Practice' er velegnet til at beskrive og undersøge betydningen og karakteristika af disse nøgleaktiviteter.

Facilitering og koordinering af samarbejde mellem CoP'er skal sikre, at samarbejdet får funktionsdygtige betingelser og rammer. Dette omfatter blandt andet, at der skabes rum og infrastruktur, samt at der på de enkelte institutioner skabes forståelse for denne type aktivitet. Koordinering af CoP'er skal fremme samspillet mellem dem, hvilket stiller forholdsvis store krav til facilitering og ledelse. I denne sammenhæng kan det være relevant at være opmærksom på funktionen som 'boundary brokers' (grænsegængere), som er beskrevet af Wenger (2000 \& 2009) og Kimble et al. (2010). 'Boundary brokers' er personer, som forstår kerneværdier i flere CoP'er; de kan skabe kontakt imellem disse og introducere ideer fra et CoP til et andet og på denne måde være med til at skabe rum for nye læringsmuligheder og videndeling. Med reference til Akkerman og Bakker (2011) forudsætter koordinering af samarbejde mellem CoP'er en kommunikativ forbindelse mellem de forskellige praksisser og perspektiver, og det understreger betydningen af, at organisationen råder over personer, der besidder kompetencer som grænsegængere og brobyggere.

Varetagelse af funktionen som brobygger og grænsegænger har derfor været essentiel i samarbejdet mellem DTU og RF. Ud over kommunikative kompetencer stiller en sådan opgave store krav til faglig forståelse af ingeniøruddannelse og festivalens interesser i forhold til at understøtte udvikling af relevante grænseobjekter og i særdeleshed til kommunikative kompetencer i forhold til at være samtalepartner i forbindelse med præcisering og realisering af projektideer. Derfor bør det overvejes grundigt, hvordan varetagelse af opgaven kan understøttes af et meningsfuldt institutionelt set-up.

\section{Institutionelt set-up - platform for praksisncert loeringsmiljø}

Samarbejdet har forløbet siden 2010, og det har resulteret i udvikling af et institutionelt setup, som studieprojekterne er forankret i (illustreret på Figur 4). På figuren refererer de blå pile og bokse til de strategiske ledelsesniveauer hos henholdsvis DTU og RF. Særligt i starten af samarbejdet var der årlige møder mellem ledelserne fra de to organisationer, hvor forventninger, erfaringer og omfang af samarbejdet blev diskuteret og afstemt. Studieprojekterne (grønne bokse og pile) gennemføres med vejledning fra en DTU-underviser og i samarbejde med en kontaktperson fra RF (røde bokse og pile). De gule bokse og pile repræsenterer det daglige arbejde. På DTU er to ingeniørstuderende ansat som koordinatorer til at varetage og være ansvarlige for det daglige arbejde, og festivalen har etableret gruppen RF Student Platform til at varetage festivalens interesser i samarbejdet. En fuldmægtig på DTU er ansvarlig projektleder for hele DTU's del af samarbejdet. Det er vores erfaring, at den åbne og uformelle dialog mellem DTU-koordinatorerne og RF Student Platform har været altafgørende for samarbejdets løbende udvikling og succes, og vi har derfor placeret disse to grupper som essentielle koordinatorer centralt i midten af det institutionelle set-up. 


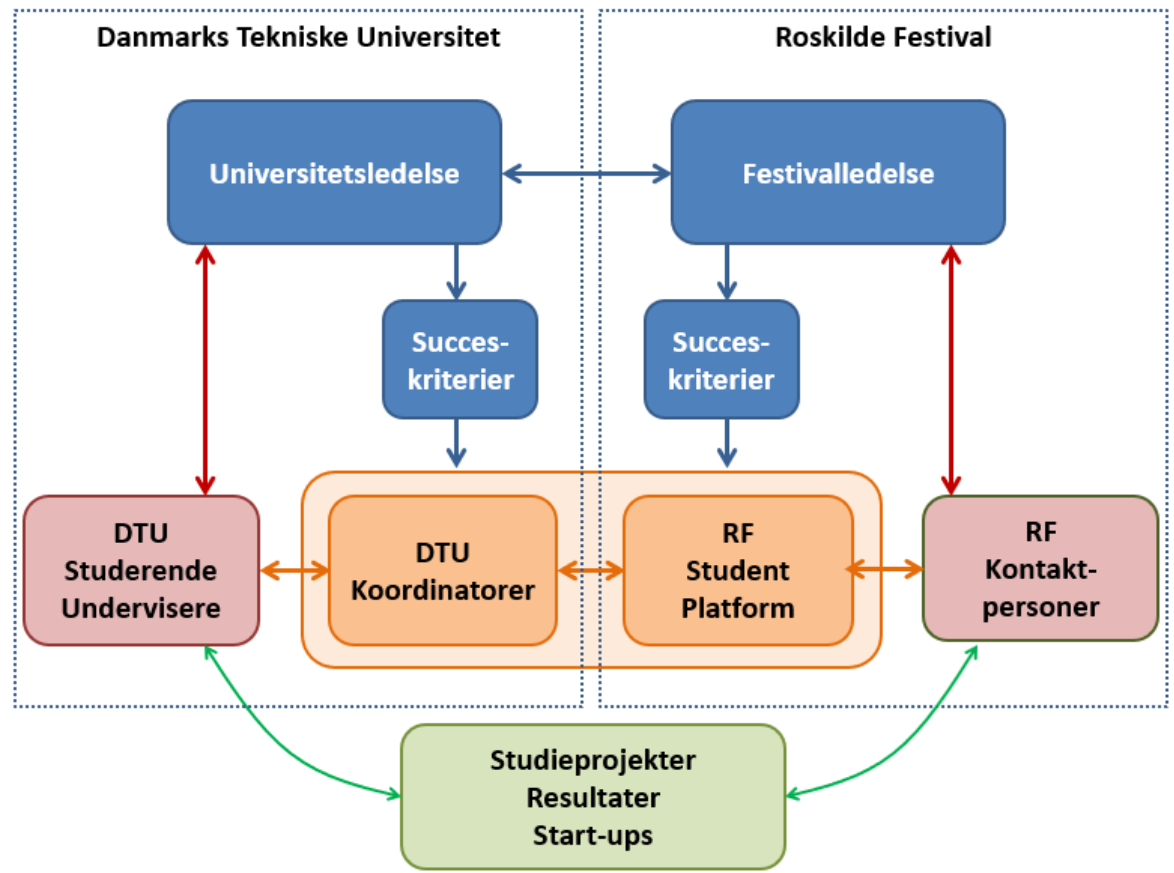

Figur 4. Institutionelt set-up for studiesamarbejdet mellem Danmarks Tekniske Universitet og Roskilde Festival. De blå bokse og pile indikerer tilpasning til den overordnede målsætning med samarbejdet. De røde bokse og pile indikerer ressourceallokering og strategiske mål. De gule bokse og pile indikerer det daglige arbejde i form af dialog, netværk, møder, facilitering, koordinering, sparring, kontrakter, støttefunktioner m.m. De grønne pile og bokse indikerer vejledning, projektarbejde og resultater.

En åben invitation til studerende, undervisere og festivalaktører er starten på at identificere og udforme projektideer til årets festival, og i denne fase tilbyder både DTU-koordinatorerne og RF Student Platform sparring og feedback på projektideer. Den indledende fase resulterer for det meste i mange relevante ideer og projektforslag, og DTU-koordinatorerne og RF Student Platform udvælger i fællesskab projekter til årets festival. I udvælgelsen lægges der vægt på projekternes relevans, realiserbarhed, økonomi, kvalitet og innovationspotentiale. I vurderingen af et studie-projekts kvalitet inddrages ofte synspunkter fra den ansvarlige underviser, som har de faglige kompetencer og viden om læringsmål.

En strukturel udfordring i samarbejdet er årshjulene for de to organisationer. På DTU er det svært at engagere studerende i studieprojekter før februar-marts måned. På dette tidspunkt er planlægningen af årets festival i den afsluttende fase, da det kan kræve et til to år at planlægge et så stort arrangement som Roskilde Festival. Det betyder, at det kan være et puslespil for DTU-koordinatorerne og RF Student Platform at få studieprojekterne placeret på festivalen, men heldigvis lykkes det som regel gennem dialog mellem parterne, da studieprojekterne i festivalsammenhæng er forholdsvis små projekter, og da der gensidigt er interesse for at skabe plads til studieprojekterne.

\section{Strategiske succeskriterier}

I hele perioden har det været afgørende, at samarbejdet har været værdiskabende for begge parter. Derfor har strategiske succeskriterier fra både DTU og RF fået betydelig opmærksomhed og været væsentlige overordnede pejlemærker for både DTU-koordinatorerne og RF Student Platform i de løbende beslutningssituationer. Dette betyder, at 'Conceive' fasen i 
CDIO-konceptet ikke blot er af betydning for de studerende men også for DTUkoordinatorerne og RF Student Platform, da det har været nødvendigt at kunne argumentere for de overordnede perspektiver i de udvalgte studieprojekter i relation til de strategiske succeskriterier. Succeskriterierne er vist i Tabel 2.

\begin{tabular}{|c|c|}
\hline Danmarks Tekniske Universitet & Roskilde Festival \\
\hline $\begin{array}{l}\text { - Studieprojekter skal opfylde læringsmål i inge- } \\
\text { niøruddannelse, og de studerende skal opnå } \\
\text { ECTS point for deres studieprojekt. } \\
\text { - Studieprojekter med fokus på innovation og } \\
\text { entreprenørskab har høj prioritet, og de stude- } \\
\text { rende opfordres til at etablere start-ups. } \\
\text { - Samarbejdet skal være en mulighed for stude- } \\
\text { rende på alle DTU's ingeniøruddannelser. } \\
\text { - De studerende skal gennem deres studiepro- } \\
\text { jekt opnå kompetencer i forhold til at forstå } \\
\text { værdiskabelse for kunder. Derfor skal pro- } \\
\text { jekterne være relevante for festivalen. }\end{array}$ & $\begin{array}{l}\text { - RF vil gerne tilbyde et læringsmiljø for unge } \\
\text { under uddannelse. } \\
\text { - En betydelig del af studieprojekterne skal } \\
\text { bidrage til realisering af festivalens sociale og } \\
\text { miljømæssige bæredygtighedsstrategi. } \\
\text { - Festivalen har en ambition om at være testfa- } \\
\text { cilitet for nye produkter og serviceydelser, } \\
\text { som vil være relevante ikke blot for festivalen } \\
\text { men for andre begivenheder og aktiviteter } \\
\text { (f.eks. alternative boformer, midlertidige bo- } \\
\text { sættelser). På denne måde håber festivalen at } \\
\text { være med til at understøtte innovation og en- } \\
\text { treprenørskab i et bredere samfundsmæssigt } \\
\text { perspektiv. }\end{array}$ \\
\hline
\end{tabular}

Tabel 2. Strategiske succeskriterier for henholdsvis DTU og RF for studiesamarbejdet.

\section{Resultater}

Det er frivilligt både for studerende og undervisere at deltage i samarbejdet. Studieprojekterne med RF er et tilbud, og frivilligheden er vigtig, da denne type studieprojekter ofte er mere tidskrævende for både studerende og undervisere end traditionelle kurser. Det er vores erfaring, at for langt de fleste både studerende og undervisere er den ekstra arbejdsindsats fuldt ud acceptabel, da der er mange sjove oplevelser og interessante læringsmuligheder forbundet med studieprojekterne.

Mange studerende har været interesserede i at deltage med et studieprojekt, og vi har gennemført spørgeskemaundersøgelser, som viser, at langt de fleste vil anbefale deres medstuderende at deltage i samarbejdet. Spørgeskemaundersøgelsen indikerer, at mange studerende er overraskede over, at projekter med eksterne partnere har et forholdsvis højt tidsforbrug og kompleksitet sammenlignet med skemalagt undervisning. Roskilde Festival er et stærkt brand blandt unge mennesker i Skandinavien, og det er vores opfattelse, at de studerende finder det attraktivt og nok også sejt at være medskaber på festivalen.

\section{Overblik over antal studerende og studieprojekter}

Detaljerede beskrivelser af studieprojekter kan findes på hjemmesiden 'Roskilde Festival powered by DTU Students' (http://www.roskilde.dtu.dk). Tabel 3 præsenterer for perioden 2010-2018 en opgørelse over antallet af studerende, projekter, kontaktpersoner fra festival, DTU-undervisere samt repræsenterede uddannelser. 


\begin{tabular}{|c|c|c|c|c|c|}
\hline Ar & Deltagere & Projekter & Antal uddannelser & RF-kontaktpersoner & Underviser \\
\hline 2010 & $20^{*}$ & 2 & Ikke registreret & Ikke registreret & Ikke registreret \\
\hline 2011 & $20^{*}$ & 7 & Ikke registreret & Ikke registreret & Ikke registreret \\
\hline 2012 & $130^{\star}$ & 20 & Ikke registreret & Ikke registreret & Ikke registreret \\
\hline 2013 & 99 & 25 & 14 & 21 & 21 \\
\hline 2014 & 101 & 23 & 17 & 12 & 17 \\
\hline 2015 & 90 & 21 & 19 & 16 & 12 \\
\hline 2016 & 87 & 19 & 22 & 16 & 16 \\
\hline 2017 & 83 & 21 & 21 & 18 & 16 \\
\hline 2018 & 85 & 22 & & & 16 \\
\hline
\end{tabular}

Tabel 3. Antal deltagere, projekter, kontaktpersoner, undervisere og repræsenterede uddannelser i perioden 2010-2018. Stjernen indikerer estimerede antal baseret på ufuldstændige historiske data. Samarbejdets arnested har været græsrodsbaseret, hvilket afspejler det lave antal deltagere over de første år.

Projekterne har omfattet mange forskellige ingeniørmæssige discipliner: fødevarer, afkøling af drikkevarer, energiproduktion, energieffektivitet, publikumsinvolvering, demonstration af nye teknologier, infrastruktur, hygiejne, vandforsyning, publikumsadfærd, affaldshåndtering, akustik, workshops for festivalgæsterne m.m. Det er derfor vores opfattelse, at samarbejdet tilbyder en stor diversitet i projektmuligheder af relevans for ingeniøruddannelserne, hvilket understøttes af opgørelsen over deltagende uddannelser i perioden 2013-1018. Samarbejdet har i denne periode studerende fra 27 ud af DTU's 63 ingeniøruddannelser. På grund af karakteren af festivalen er det forventeligt, at uddannelser inden for akustik, elektricitet, miljø, mekanik og design er hyppigt repræsenteret, hvilket er i overensstemmelse med resultaterne fra Malmqvist et al. (2015), der viser, at ingeniørdiscipliner inden for mekanik, elektricitet og computerteknologi er hyppigst repræsenteret i forhold til implementering af CDIO i uddannelserne. Tabel 4 giver et overblik over top 10-repræsenterede DTU-uddannelser i samarbejdet mellem DTU og RF.

\begin{tabular}{|l|c|}
\hline Uddannelsesretning & Antal studerende \\
\hline Informationsteknologi & 11 \\
\hline Miljøteknologi & 44 \\
\hline Fysik og nanoteknologi & 10 \\
\hline Bioteknologi & 18 \\
\hline Bygningsteknologi & 32 \\
\hline Produktion og konstruktion & 20 \\
\hline Elektroteknologi & 61 \\
\hline Lyd og akustik teknologi & 60 \\
\hline Design og innovation & 155 \\
\hline BEng maskinteknik & 11 \\
\hline Andre & 107 \\
\hline
\end{tabular}

Tabel 4. Overblik over top 10-repræsenterede uddannelser i perioden 2013-2018. Kategorien 
'Andre' omfatter studerende fra 17 forskellige uddannelser. Studerende, der har deltaget i administrative støttefunktioner, er ikke medtaget.

For DTU er et strategisk succeskriterium, at samarbejdet skal være tilgængeligt for studerende på alle DTU's uddannelser. Når vi ser på opgørelserne over deltagende studerende, må vi konstatere, at studerende fra diplomuddannelserne er stærkt underrepræsenterede. Forklaringen på dette er, at disse uddannelser har langt mindre valgfrihed end bachelor- og kandidatuddannelserne, og derfor er det meget vanskeligt for de studerende på diplomuddannelserne at få indpasset studieprojekter i festivalregi i deres uddannelsesforløb.

\section{Studieprojekter med fokus på studenterdrevne start-ups}

Innovation og entreprenørskab er vigtige succeskriterier for begge institutioner (Tabel 2). DTU-koordinatorerne og RF Student Platform har derfor været særlige opmærksomme på at identificere og understøtte projekter med potentiale til at blive en start-up-virksomhed. En fremgangsmåde $\mathrm{i}$ denne proces er at vurdere projektet baseret på elementerne i CDIOkonceptet. Det kan selvfølgelig være vanskeligt at spotte potentielle start-ups, og flere projekter har af mange forskellige grunde ikke udvist det forventede resultat (f.eks. tekniske vanskeligheder, samarbejdsproblemer).

I vores arbejde er vi blevet inspireret af Ruth Grahams tanker om universitetsmiljøer, der understøtter entreprenørskab og innovationskulturer (Graham 2013 \& 2014). Graham pointerer betydningen af, at entreprenørskab og innovation er en integreret del af universitetets strategi, og at ledelsens opbakning og anerkendelse af konkrete aktiviteter er essentielle for at sikre succesfulde projekter. Et andet centralt aspekt er, at de koordinerende og understøttende aktiviteter varetages af studerende. Det er også vores erfaring, at begge forhold er vigtige, og det er særligt betydningsfuldt, at DTU-koordinatorerne selv er ingeniørstuderende, som kan møde de studerende i øjenhøjde. Graham (2018) argumenterer ydermere for, at fremtidens førende uddannelsesinstitutioner inden for ingeniørvidenskab i højere grad end tidligere kommer til at flytte deres uddannelsestilbud ud af traditionelle auditorier og tilbyde udadvendte problemorienterede og projektorganiserede undervisningstilbud, der er såvel socialt som samfundsmæssigt relevante og værdiskabende.

Fra den samlede portfolio af studieprojekter har vi udvalgt de projekter, som har resulteret i studenterdrevne start-ups, se Tabel 5. Inklusionskriteriet har været projekter, der har registeret et CVR-nummer.

I forbindelse med de studenterdrevne start-ups har samarbejdet haft opmærksomhed på rettighederne til de enkelte projekter. En del af samarbejdet omfatter derfor udarbejdelse af en kontrakt, der præciserer, at de studerendes har (IPR) til deres egne projektideer. Festivalen fungerer i samarbejdet alene som et Living Lab til test af prototyper.

I den åbne litteratur har flere forfattere understreget betydning af feedback fra potentielle interessenter og brugere tidligt i innovationsprocessen (f.eks. Ulrich \& Eppinger 2007). Tilbagemeldinger fra de studerende viser, at de unikke ønsker og behov, som festivalen og dens publikum repræsenterer, giver de studerende mulighed for at udvikle produkter og serviceydelser til nichemarkeder, som det ellers kan være vanskeligt at få adgang til uden insiderviden og tæt samarbejde med interessenterne. I tråd med Living Lab konceptet foregår dette i en åben proces, hvor involverede aktører betragtes som medskabere. 


\begin{tabular}{|c|c|c|c|}
\hline År & Projekt & Beskrivelse & Billede \\
\hline 2011 & $\begin{array}{l}\text { Bio-fuel Genera- } \\
\text { tor }\end{array}$ & $\begin{array}{l}\text { Fritureolie til elektricitetsproduktion. Dieselge- } \\
\text { nerator ombygges til at benytte brugt friture- } \\
\text { olie fra fødevarestandene på festivalen. }\end{array}$ & \\
\hline 2012 & Volt & $\begin{array}{l}\text { Bærbar mobiloplader. En lille bærbar oplader } \\
\text { med bytteservice, der oplader mobilen i lom- } \\
\text { men. Brugeren betaler depositum og ser- } \\
\text { viceydelse. }\end{array}$ & \\
\hline 2012 & Cutlab & $\begin{array}{l}\text { Modulære og sammenfoldelige siddemøbler. } \\
\text { Et CNC-system kaldet 'kubio' til fleksible sidde- } \\
\text { pladser. Produktet har modtaget en 'Red Dot } \\
\text { Design Award'. }\end{array}$ & \\
\hline 2013 & DropBucket & $\begin{array}{l}\text { DropBucket er en skraldespand, der kan op- } \\
\text { sættes til særlige lejligheder. Det er en udfolde- } \\
\text { lig affaldsbeholder, der er fremstillet i gen- } \\
\text { brugsbølgepap. }\end{array}$ & \\
\hline 2013 & PeeFence & $\begin{array}{l}\text { Konceptet er et blødt polymermateriale, der } \\
\text { nemt kan foldes til et pissoir og ophænges. } \\
\text { Produktet har modtaget en 'Danish Design } \\
\text { Award'. }\end{array}$ & \\
\hline 2014 & Sitpack & $\begin{array}{l}\text { En sammenklappelig stol med justerbar sidde- } \\
\text { højde. }\end{array}$ & \\
\hline 2015 & Paprnote & $\begin{array}{l}\text { Et digital-fysisk personligt gækkebrev, der fa- } \\
\text { brikeres interaktivt under festivalen. }\end{array}$ & \\
\hline 2017 & Allumen & $\begin{array}{l}\text { Allumen har til formål at bruge millioner af } \\
\text { mikroskopiske, lysende alger (bioluminescens) } \\
\text { til at undervise i naturens egen lyskilde og } \\
\text { fremstille inspirerende produkter. }\end{array}$ & \\
\hline 2017 & Containdom & $\begin{array}{l}\text { Koncept, som gør det nemmere for ejerman- } \\
\text { den at skille sig af med sit brugte kondom på } \\
\text { en ordentlig måde, så det ikke ligger og flyder } \\
\text { på jorden. }\end{array}$ & \\
\hline 2017 & Glød & $\begin{array}{l}\text { Bærbar lanterne specielt designet til musikfe- } \\
\text { stivaler og udendørs sammenkomster. Inter- } \\
\text { aktive farvede lyseffekter i forhold til lyd i } \\
\text { omgivelserne. }\end{array}$ & \\
\hline 2018 & Alarmified & $\begin{array}{l}\text { Alarmified er en lille og alsidig tyverialarm, der } \\
\text { midlertidigt kan fastgøres på personers ejende- } \\
\text { le. Når alarmen er aktiveret, vil en høj sirene } \\
\text { lyde i tilfælde af, at den låste genstand bevæ- } \\
\text { ges. }\end{array}$ & \\
\hline 2018 & BAENK & $\begin{array}{l}\text { Genanvendeligt, modulært siddemodul, som } \\
\text { nemt kan sættes op i forskellige kombinationer } \\
\text { alt efter festivalens ønsker og behov til indret- } \\
\text { ning af fællesområder. }\end{array}$ & \\
\hline 2018 & DrinkSaver & $\begin{array}{l}\text { DrinkSaver er i høj grad tiltænkt personer, som } \\
\text { lider af en form for funktionsnedsættelse. } \\
\text { Formålet at mindske spild af drikkevarer til } \\
\text { koncerter og på festivaler. }\end{array}$ & \\
\hline
\end{tabular}


Tabel 5. Korte beskrivelser af studenterdrevne start-ups med angivelse af deres opfindelsesår/første år på Roskilde Festival med foto af deres produkt eller serviceydelse.

Vi har gennemført en spørgeskemaundersøgelse med de studieprojekter, der resulterede i en start-up, og fra denne undersøgelse har vi lært følgende:

- Størstedelen af projekterne havde deres første møde med potentielle brugere/kunder på festivalen. Grupperne har meldt tilbage, at disse erfaringer var særdeles betydningsfulde og effektfulde i læringsprocessen omkring markedsføring af produkter og serviceydelser.

- Living Lab-læringsmiljøet blev af de studerende vurderet som særdeles udbytterigt i forhold til at afprøve designløsningen og opnå teknisk indsigt i produkter/serviceydelser. En indsigt, som efterfølgende blev anvendt som direkte inspiration til ændringer og forbedringer af deres designs.

- Der er rum for forbedringer i forhold til en tættere forbindelse mellem platformen for samarbejdet mellem DTU og RF og de øvrige innovationsinitiativer og -aktiviteter på DTU. Det er indtrykket, at der ikke er tilstrækkelig opmærksomhed på at understøtte den videre innovationsproces, når projekterne ikke længere er en del af platformen.

- De studerende vil i høj grad gerne anbefale DTU-RF-samarbejdet til medstuderende med et tilsvarende ønske om studenterdrevene start-ups.

\section{Lessonslearned - praksisnært læringsmiljø i ingeniøruddannelser}

\section{Nødvendigheden af et fleksibilitet loeringsmiljø}

Som det fremgår af Tabel 2, er det en målsætning for DTU, at festivalsamarbejdet skal være tilgængeligt for alle ingeniøruddannelserne på DTU og for studerende på alle niveauer i uddannelsesforløbet. Hovedparten af aktiviteterne skal være meriterende. Diversiteten i faglige interesser og variationen i uddannelsesniveau har betydet, at der er udviklet og tilbydes fire forskellige former for deltagelse med studieaktiviteter på selve festivalen, se Tabel 6 .

\begin{tabular}{|l|l|l|}
\hline Aktivitet & Karakteristika & Merit \\
\hline $\begin{array}{l}\text { Kurser målrettet festivalen } \\
\text { (akustik og affaldshåndte- } \\
\text { ring) }\end{array}$ & $\begin{array}{l}\text { Kurser udbudt af undervisere ansvarlige for kursets indhold } \\
\text { og læringsmål. }\end{array}$ & Ja \\
\hline $\begin{array}{l}\text { Projekter om festivalcases i } \\
\text { eksisterende kurser }\end{array}$ & $\begin{array}{l}\text { Underviserne identificerer et tema for et kursus, som er } \\
\text { relevant for festivalen, f.eks. forbedring af festivaloplevelsen } \\
\text { for handikappede mennesker. }\end{array}$ & Ja \\
\hline Specialkurser & $\begin{array}{l}\text { Indholdet af et specialkursus aftales og defineres mellem de } \\
\text { studerende, underviser på DTU og en kontaktperson fra RF. }\end{array}$ & Ja \\
\hline $\begin{array}{l}\text { Administrative støttefunkti- } \\
\text { oner og studerendes egne } \\
\text { projekter }\end{array}$ & $\begin{array}{l}\text { DTU har hvert år en stand (Tech Lab) på festivalen, som be- } \\
\text { mandes af studerende. Studerende kan endvidere i begræn- } \\
\text { set omfang deltage med egne projekter. }\end{array}$ & Nej \\
\hline
\end{tabular}

Tabel 6. Fire forskellige former for studieaktiviteter i samarbejdet mellem DTU og Roskilde Festival.

I forhold til fleksibilitet i studieprojekter er det også en mulighed at gennemføre samarbejde på andre tidspunkter end under selve festivalen. Et eksempel på dette er kurset 'Implementering og performance management', som i undervisningen har benyttet en case om festivalens bæredygtighedsstrategi. Her skulle de studerende gennemføre interviews med aktører $\mathrm{i}$ festivalen omkring implementering af strategien i festivalens daglige arbejde. På grundlag af 
kursets teoretiske pensum og empirien indsamlet gennem interviews udarbejdede de studerende anbefalinger til, hvordan festivalen kan forbedre implementering af strategien.

\section{Paedagogiske praksisser i loeringsmiljøet}

Målsætningen om fleksibilitet i læringsmiljøet har bevirket, at der er to overordnede pædagogiske praksisser. Den ene er en anvendelsesorienteret praksis, hvor de studerende først deltager i teoretisk undervisning på DTU og dernæst arbejder med en veldefineret opgave inden for det teoretiske felt. Den anvendelsesorienterede praksis omfatter to kurser (akustik og affaldshåndtering). Den anden er en innovations- og entreprenørskabsorienteret praksis, som giver de studerende mulighed for at afprøve entreprenørskab på egen krop, og dette omfatter evnen til at se muligheder, at konceptualisere ideer, at tænke strategisk, at skabe relationer, at indgå i komplekse arbejdsprocesser, alt sammen med udgangspunkt i et fagligt perspektiv (Jørgensen \& Hjortsø 2015). Begge pædagogiske praksisser har høj ingeniørmæssig faglighed som grundlag.

For både DTU og RF er studieaktiviteter med fokus på entreprenørskab og innovation vigtige succeskriterier. Med reference til Jørgensen og Hjortsø (2015) er der tale om, at læringsmålet er en øget handlingskraft hos de studerede, så de kan overkomme udfordringer i innovations- og implementeringsprocesser. Mange studieprojekter har resulteret i start-ups (Tabel 5), hvilket indikerer, at de studerende har været i stand til at overkomme disse udfordringer. I denne sammenhæng skal det bemærkes, at langt de fleste studieprojekter ikke har resulteret i start-ups af mange forskellige årsager. Først og fremmest kan projekternes formål være at bringe ny viden til festivalen og uden at have kommercialisering i sigte. I andre tilfælde har de studerende erfaret, at deres produkt ikke i tilstrækkelig grad løser en specifik problemstilling, eller de studerende har ikke ønsket at videreføre samarbejdet i projektgruppen. I disse tilfælde er festivalens udbytte, at studieprojekterne eksponerer festivalorganisationen overfor ny teknologi, der kan stimulere udvikling, adoption af denne nye teknologi samt komplimentere de eksisterende kompetencer hos festivalen. En sådan tilgang til innovation via samarbejde med universiteter kan også findes reflekteret i den eksisterende forskning omkring universitetssamarbejder (Frølund et al. 2019), (McConnel \& Cross 2019). Her bør ydermere nævnes, at begge ledelser har udvist forståelse for, at de fleste projekter alene er på festivalen en enkelt gang med det læringsmål at styrke de studerendes professionelle kompetencer inden for tværgående problemorientering og projektorganisering, hvilket er udtrykt af Akkerman og Bakker (2011): [ ...work and learning are not only about becoming an expert in a particular bounded domain but also about crossing boundaries].

Vi har konstateret, at studieprojekter på festivalen primært appellerer til entreprenante, kreative og selvkørende studerende, som kan og gerne vil klare mange udfordringer på egen hånd. Denne erfaring er i overensstemmelse med Jørgensen og Hjortsø (2015), som pointerer, at den entreprenante studerende er karakteriseret ved en empatisk, analytisk, kreativ, beslutsom og selvsikker adfærd. I fremtiden bør det overvejes, om der skal udvikles tilbud til studerende, der har brug for undervisningsforløb med en veldefineret struktur. Det kan til eksempel være særligt fagnørdede studerende, der måske kunne have stort udbytte af at indgå i en projektgruppe med andre faggrupper.

Med henvisning til Jørgensen og Hjortsø (2015) er mange akademikere utroligt gode til at analysere problemer, men dette løser ikke problemer. Vi mener, at fokus på faserne i CDIOkonceptet samt fokus på formulering af grænseobjekter både giver de studerede mulighed 
for at analysere problemer men samtidig komme skridtet videre og arbejde med at udvikle fagligt funderede og værdiskabende løsninger.

Som nævnt har vi gennem en spørgeskemaundersøgelse erfaret, at mange studerende er overraskede over, at projekter med festivalen har et forholdsvis højt tidsforbrug og kompleksitet sammenlignet med skemalagt undervisning. Denne form for læring er nyttig, da samfundets krav til studerendes kernefaglighed er stigende samtidig med øgede forventninger til, at studerende kan indgå i komplekse sammenhænge på tværs af fag og discipliner. Her kan innovations- og entreprenørskabspædagogikken være en del af løsningen, da den handler om at bringe innovationsprocessen ind i en fagdisciplinær kontekst, hvor den studerende ved at arbejde med sin egen faglighed udvikler sit blik og sin evne til at skabe værdi gennem at sætte sin egen faglige viden i spil. (Jørgensen \& Hjortsø 2015). Dette er på linje med anbefalinger fra Chamorro-Premuzic og Frankiewicz, (2019), som pointerer nytten af såkaldte 'softskills' hos universitetskandidater, f.eks. ledelse af team samt åbenhed overfor andres synspunkter.

I samarbejdet mellem DTU og festivalen har det været afgørende, at de forskellige former for studieaktiviteter har en faglig underviser eller vejleder, som sikrer det faglige niveau i de studerendes arbejde foruden en opfyldelse af læringsmål og andre uddannelsesmæssige krav, samt at de studerende opnår ECTS point for deres studieprojekt.

\section{Det overordnede set-up}

Opbakning fra begge ledelser har været en essentiel forudsætning for samarbejdet mellem DTU og RF. Opbakningen har været i form af ressourceallokering og økonomi sammen med lydhørhed og tydelig anerkendelse af resultaterne af samarbejdet. Opbakningen har været til både studerende, medarbejdere og festivalaktører. Dette kommer blandt andet til udtryk ved, at der hvert år arrangeres en rundvisning på festivalpladsen, hvor omkring 60-70 medarbejdere fra DTU har mulighed for at se og høre om årets studieprojekter, og i 2017 besøgte DTU's ledelse og direktørkreds festivalen, Figur 5. I korthed kan ledelsesstilen i begge organisationer betegnes som 'bottom-up', rummelig med plads til fejl, anerkendende og visionsdrevet med fokus på de studerende som medskabere på festivalen med ansvar og ejerskab for deres egne projekter.

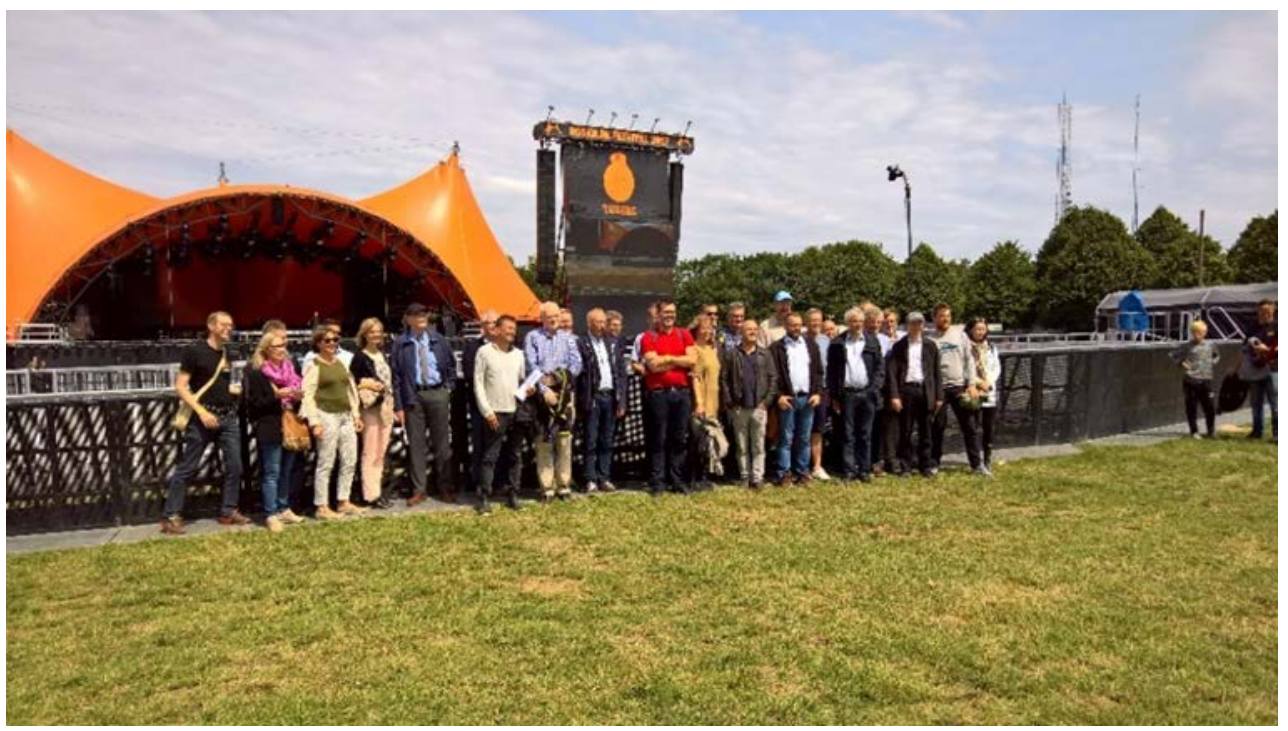

Figur 5. DTU's ledelse og direktørkredsen besøger Roskilde Festival i 2017. 
Både på DTU og festivalen har samarbejdet været forankret i støttefunktioner og ikke på et specifikt universitetsinstitut eller i en festivalafdeling. Det er vores opfattelse, at denne forankring af samarbejdet har været med til at skabe en robust organisering med rum for nye ideer uafhængigt af enkelte fagområders og aktørers særinteresser.

Det institutionelle set-up er udviklet gennem en længere årrække og tilpasset DTU's ønsker. Det er et forholdsvis ressourcekrævende set-up, og det kan overvejes, om ressourcerne kan anvendes mere optimalt på andre måder.

\section{Voerdiskabelse og succeskriterier}

Som nævnt i indledningen ønsker DTU et tæt samarbejde mellem virksomheder og studerende med fokus på, at de studerende får mulighed for at afprøve prototyper og få sparring fra virksomheder. Tilbagemeldingerne fra spørgeskemaundersøgelserne viser, at de studerende ønsker feedback på deres projekt i prototypestadiet, og alle respondenterne svarer, at de i nogen eller høj grad har gennemført ændringer i deres produkt som resultat af afprøvningen. RF ønsker at være testfacilitet for nye produkter og serviceydelser, som vil være relevante ikke alene for festivalen men i et bredere samfundsmæssigt perspektiv. Flere produkter er efterfølgende benyttet andre steder end på Roskilde Festival (f.eks. Volt, PeeFence, Dropbucket, Cutlab). Co-branding er væsentligt for begge organisationer. DTU informerer i rekrutteringsaktiviteter om muligheden for studieprojekter på Roskilde Festival (f.eks. Åbent Hus).

Festivalen ønsker som del af strategien for social ansvarlighed at tilbyde et læringsmiljø for unge under uddannelse. I denne forbindelse skal det nævnes, at festivalen har og har haft samarbejde om studieprojekter med flere uddannelsesinstitutioner. Samarbejdet kan have forskellige omfang og indhold, men fælles karakteristika har været opbakning fra ledelsen samt en fast forankring i en understøttende faglig og organisatorisk struktur. Denne erfaring er i overensstemmelse med Jørgensen og Hjortsø, (2015), der pointerer, at kreativitet og innovation i undervisning styrkes af en veltilrettelagt struktur.

\section{DTU-koordinatorer og RF Student Platform}

Både DTU-koordinatorerne og RF Student Platform arbejder året rundt med at etablere og vedligeholde netværk, da planlægning af en festival foregår løbende og tager et til to år. For at opretholde opmærksomheden omkring mulighederne i samarbejdet udarbejdes jævnligt små artikler i interne medier i begge organisationer, og her er der særligt fokus på at fortælle om succesfulde innovative studieprojekter. En tæt og god dialog mellem DTUkoordinatorerne og RF Student Platform har været sikret ved 6-8 årlige møder og kontakt via mails med henblik på at evaluere årets projekter samt diskutere planer og ideer for den kommende festival.

Der er mange studieprojekter, og det kan være en udfordring at bevare overblikket i forhold til proces, resultater og læring i det enkelte projekt. Det betyder også, at det kan være vanskeligt at få overblik over, hvordan de enkelte projekter efterfølgende udvikler sig. En anden stor udfordring er at identificere egnede studieprojekter og finde den rette snitflade af interesse for begge parter. En tredje udfordring er, at det kan være svært at give forskellige aktører rettidige klare svar på, om projekterne gennemføres eller ej (særligt tidligt på året). I uddannelsesregi kan dette give vanskeligheder i forhold til kursustilmelding, i forhold til at finde vejledere mv. For festivalen kan det betyde forstyrrelse omkring planlægning og allokering af plads osv. 
DTU-koordinatorerne og RF Student Platform har en afgørende funktion i samarbejdet. Man kan sige, at de to grupper udgør samarbejdets maskinrum, da de fungerer som brobyggere og grænsegængere samt er med til at identificere og præcisere projekter af fælles interesse (grænseobjekter). De varetager i fællesskab opgaver på fem dimensioner: (i) forståelse af kerneværdier og strategiske succeskriterier i begge organisationer og funktion som en slags 'tolke' og samtalepartnere i dialogen mellem de to organisationer, (ii) god forståelse af den problemorienterede og projektorganiserede undervisningsform, herunder afgrænsning og fokusering af projekter, (iii) proaktivitet i forhold til videndeling året rundt mellem de to organisationer, (iv) professionel og praktisk servicering af studieprojekterne og (v) faglig styrke og personligt mod til at udvælge og afvise studieprojekter.

\section{Konklusion}

Vi har argumenteret for, at infrastrukturen i en non-profit musikfestival med et internationalt brand er et pædagogisk attraktivt Living Lab-læringsmiljø for ingeniørstuderende med mulighed for udfoldning af CDIO-konceptet $\mathrm{i}$ ingeniørmæssig problemløsning samt med mulighed for at erhverve kompetencer til at indgå i projektorganisering på tværs af organisationer.

Samarbejdet mellem DTU og RF kan ses som en del af den udvikling, universitetspædagogikken gennemløber i disse år med en stadig stigende opmærksomhed på og interesse for at skabe åbne og praksisnære innovationsmiljøer med eksterne samarbejdspartnere, hvor de studerende som del af deres uddannelse kan gennemføre studierelevante aktiviteter, der samtidigt er værdiskabende socialt og samfundsmæssigt.

Vi har erfaret, at både formen og omfanget af samarbejdet mellem DTU og RF er både udfordrende og ressourcekrævende, og for at få samarbejdet til at blomstre og opnå de ønskede resultater er det nødvendigt at etablere et robust institutionelt set-up, som kan understøtte aktiviteterne.

Vi håber, vores erfaringer kan være til inspiration for andre uddannelsesinstitutioner, som $ø n s k e r$ at etablere tilsvarende samarbejde med eksterne partnere.

\section{Tak}

Forfatterne vil gerne sende en stor tak til alle, der gennem årene har deltaget i samarbejdet. Deres opbakning, anerkendelse og engagement har været altafgørende for samarbejdets succes. En særlig tak til de entusiastiske, dedikerede og kreative ingeniørstuderende, som har bidraget med godt humør samt innovative projekter og ideer.

\section{Referencer}

Aarhus Universitet (2012). Håndbog i CDIO ved ASE. En beskrivelse af ingeniørprofiler og et arbejdsredskab for uddannelsesudvikling, Aarhus Universitet, School of Engineering.

Akkerman, S.F., Bakker, A. (2011). "Boundary Crossing and Boundary Objects", Review of Educational Research, 81/2, 132-169.

Almirall, E., Wareham, J. (2011). Living Labs: Arbiters of Mid- and Ground- Level Innovation. Technology Analysis and Strategic Management.

Andreasen et al. (2015), Conceptual Design, Springer International Publishing 
Askehave, I. (Ansv.), Prehn, H.L., Pedersen, J., Pedersen, M.T. (2015). PBL - Problembaseret læring, Aalborg Universitet.

Bergvall-Kareborn, B., Stahlbrost, A. (2009). Living Lab: an open and citizen-centric approach for innovation. Int. J. Innov. Reg. Dev. 1, 356-370.

https://doi.org/10.1504/IJIRD.2009.022727

Bowker, G.C.; Star, S.L. (1999). Sorting Things Out. Classification and Its Consequences, The MIT Press.

Chamorro-Premuzic, T., Frankiewicz, B. (2019). Does Higher Education Still Prepare People for Jobs?,Harward Business Review, https://hbr.org/2019/01/does-higher-education-stillprepare-people-for-jobs

Cohen, E.B. (2009). Growing Information: Part I. Informing Science.

Crawley, E.F.; Malmqvist, J.; Östlund, S.; Brodeur, D.R.; Edström, K. (2014). Rethinking Engineering Education. The CDIO Approach, Chapter 2, Springer International Publishing Switzer-land.

Cross, N. (2001). Engineering Design Methods: Strategies for product design, John Wiley \& Sons.

Dell'Era, C., Landoni, P. (2014). Living Lab: A Methodology between User-Centred Design and Participatory Design. Creat. Innov. Manag. 23, 137-154. https://doi.org/10.1111/caim.12061

DTU (2013). Håndbog for CDIO på DTU's diplomingeniøruddannelser, Version 2-2013.

DTU (2018). Strategy 2014-2019, http://emagstudio.win.dtu.dk/Ebooks/Corporate/Strategi_2014-2019/

Frølund, L., Murray, F., Riedel, M. (2018). Developing Successful Strategic Partnerships With Universities, MITSloan Management Review, https://sloanreview.mit.edu/article/developing-successful-strategic-partnerships-withuniversities/

Geraldi, J., Thuesen, C., Oehmen, J., Stingl, V. (2017). Doing projects. A Nordic Flavour to Manage Projects, DS Handbook 185-2017, Forlaget Dansk Standard.

Graham, R. (2013). Technology Innovation Ecosystem Benchmarking Study: Key findings from Phase 1, MIT Skoltech Initiative.

Graham, R. (2014). Creating university-based entrepreneurial ecosystems - evidence from emerging world leaders, MIT Skoltech Initiative.

Graham, R. (2018). The Global State of the art in engineering education, MIT.

IRISgroup (2018). Iværksætteri på DTU gennem to årtier - indsats, resultater og samfundsmæssige effekter. Prepared for the Technical University of Denmark.

Jensen, L.S., Özkil, A.G., Mougaard, K. (2016). Makerspaces in Engineering Education: A Case Study. Proc. Asme Int. Des. Eng. Tech. Conf. Comput. Inf. Eng. Conf. Vol 3.

Jørgensen, C.B., Hjortsø, C.N. (2015). At åbne de lukkede undervisningsrum: innovationspæ- 
dagogik/entreprenørskabsundervisning, [In:] Rienecker, L., Jørgensen, P.S. Universitetspædagogiske praksisser, Samfundslitteratur.

Kimble, C.; Grenier, C.; Goglio-Primard, K. (2010). Innovation and knowledge sharing across professional boundaries: Political interplay between boundary objects and boundary brokers, International Journal of Information Management, vol. 30, 437-444.

Krogh, L., Wiberg, M. (2013). Problemorienteret og projektorganiseret undervisning, [In:] Rienecker, L., Jørgensen, P.S., Dolin, J., Ingerslev, G.H. Universitetspædagogik, Samfundslitteratur.

Lehmann, M., Christensen, P.; Du, X., Thrane, M. (2008). “Problem-oriented and project-based learning (POPBL) as an innovative learning strategy for sustainable development in engineering education", Eur. J. Eng. Educ., vol. 33, no. 3, 283-295.

Malmqvist, J., Hugo, R., Kjellberg, M. (2015). A Survey of CDIO Implementation Globally - Effects on Educational Quality. Proceedings of the 11th International CDIO Conference, Chengdu University of Information Technology, Chengdu, Sichuan, P.R. China, June 811, 2015.

Marstrand, S. (2005). Videndeling i og mellem communities of practice, Ledelse \& Erhvervsøkonomi, 3/2005, 153-163.Miettilnen, R. (2002). How Do We Keep the Living Laboratory Alive? Learning and Conflicts in Living Lab Collaboration - ProQuest. Technol. Innov. Manag. Rev.

McConnell, D.P., Cross, S.E (2019) Realizing the Value of Industry-University Innovation Allianc-es, Research-Technology Management, 62:2, 40-48, DOI:

10.1080/08956308.2019.1563437

Nielsen, M.F. (2015. Samarbejde med eksterne partnere om studieprojekter, [In:] Rienecker, L., Jørgensen, P.S. Universitetspædagogiske praksisser, Samfundslitteratur.

Roskilde Festival (2018). www.roskilde-festival.dk

Ulrich, K. T, Eppinger S. T. (2007). Product design and development. McGraw-Hill Higher Education.

Wenger, E. (2000). Communities of practice and social learning systems, Organisation, vol. $7(2), 225-246$.

Wenger, E.; McDermott, R.; Snyder, W.M. (2002). Cultivating Communities of Practice, A guide to Managing Knowledge, Harvard Business School Press.

Wenger, E. (2009). Communities of practice and social learning systems: the career of a concept, http://wenger-trayner.com/resources/publications/cops-and-learning-systems/ 